\title{
EFEKTIVITAS PENGENDALIAN INTERNAL, KEPUASAN KERJA DAN KECENDERUNGAN KECURANGAN AKUNTANSI
}

\author{
Natalia Paranoan ${ }^{1}$, Edmondus Sadesto Tandungan ${ }^{1}$, Afian Dezi Sanda Sipi ${ }^{1}$ \\ ${ }^{1}$ Dosen UKI Paulus Makassar
}

\begin{abstract}
This study aimed to examine the effect of the internal control effectiveness and job satisfaction on the trend of accounting fraud at state-owned enterprises in Makassar. This research conducted at employees of state-owned enterprises. The data collection will be done by using survey through questionnaires taken from state-owned companies in the city of Makassar on 65 respondents and using proportional random sampling. The questionnaire will be tested for validity and reliability before collecting research data. Test requirements analysis that includes test instruments and classic assumption test including normality test, test multicoloniarity, heteroscedasticity test and linearity test. Data analysis method used simple regression analysis and multiple regression analysis.
\end{abstract}

Keywords: Internal Control, Job Satisfaction, Accounting Fraud, SOEs

\begin{abstract}
ABSTRAK
Penelitian ini bertujuan untuk menguji pengaruh efektivitas pengendalian internal dan kepuasan kerja terhadap kecenderungan kecurangan akuntansi pada perusahaan BUMN di Makassar. Penelitian ini dilakukan terhadap karyawan perusahaan BUMN. Adapun pengumpulan data akan dilakukan dengan menggunakan survey melalui kuisioner yang diambil dari perusahaan BUMN yang ada di Kota Makassar sebanyak 65 responden dan menggunakan propotional random sampling. Kuesioner akan diuji validitas dan reliabilitasnya sebelum melakukan pengumpulan data penelitian. Uji prasyarat analisis yang meliputi uji instrumen dan uji asumsi klasik yang meliputi uji normalitas, uji multikolonieritas, uji heteroskedastisitas dan uji linearitas. Metode analisis data yang digunakan adalah analisis regresi sederhana dan analisis regresi berganda.
\end{abstract}

Kata kunci: Pengendalian Internal, Kepuasan Kerja, Kecurangan Akuntansi, Perusahaan BUMN

Jurnal Akun Nabelo: Jurnal Akuntansi Netral, Akuntabel, Objektif

Volume 1/Nomor 1/Juli 2018 Jurusan Akuntansi FE-Universitas Tadulako

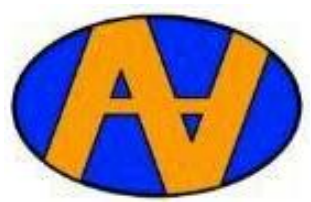




\section{A. PENDAHULUAN}

Indonesia menempati urutan ke64 negara paling korup di dunia dan peringkat pertama di tingkat Asia Pasifik (Kompasiana, 2013). Kecurangan dapat terjadi di berbagai sektor, baik di sektor swasta maupun di sektor pemerintahan. Kecurangan yang paling sering terjadi di sektor pemerintahan adalah korupsi. Indikasi adanya kecurangan dapat dilihat dari bentuk kebijakan yang disengaja dan tindakan yang bertujuan untuk melakukan penipuan atau manipulasi yang merugikan pihak lain (Thoyibatun, 2009).

Fenomena yang terjadi pada BUMN, di mana pada tahun 2007 beberapa BUMN tidak mau diperiksa oleh Badan Pemeriksa Keuangan (BPK) dan hanya mau diperiksa oleh kantor akuntan publik dalam mengaudit laporan keuangan. Tentunya hal ini mengundang pertanyaan, ada apa antara BUMN dan kantor akuntan publik, dan tentunya akan menimbulkan anggapan di kalangan BPK bahwa terjadi suatu indikasi kecurangan antara BUMN dengan kantor akuntan publik (Ariyani, 2007 dalam Rahayu, 2014).

Kecurangan (fraud) merupakan konsep hukum yang memiliki cakupan luas. Istilah kecurangan akuntansi diartikan sebagai penipuan atau kecurangan di bidang keuangan. Menurut Tunggal (2012), kecurangan diartikan sebagai "penipuan di bidang keuangan yang disengaja, yang dimaksudkan untuk mengambil aset atau hak orang maupun pihak lain". Dengan kata lain, dalam melakukan kecurangan, setiap orang atau pelaku memiliki motivasi yang beraneka ragam. Kecurangan dapat pula didefinisikan sebagai suatu perbuatan melawan hukum yang dilakukan oleh orang-orang dari dalam dan atau luar organisasi, dengan maksud untuk mendapatkan keuntungan pribadi dan/atau kelompoknya yang secara langsung merugikan pihak lain (Tuannakotta, 2007).

Ada tiga bentuk kecurangan, antara lain menurut Tuannakotta (2007), yaitu (1) penyalahgunaan atas aset adalah kecurangan yang melibatkan pencurian aktiva entitas; (2) pernyataan palsu atas laporan keuangan salah saji atau pengabaian jumlah atau pengungkapan yang disengaja dengan maksud menipu para pemakai laporan keuangan itu; dan (3) korupsi penyalahgunaan jabatan di sektor pemerintahan untuk keuntungan pribadi. Pernyataan palsu atas laporan keuangan dan penyalahgunaan aset juga dapat digolongkan sebagai kecurangan akuntansi. Hal ini berkaitan dengan salah saji yang timbul dari kecurangan dalam laporan keuangan yang timbul dari perlakuan tidak semestinya terhadap aset (SPAP 2011, SA seksi 316 paragraf 03).

Salah satu teori yang menjelaskan tentang motivasi seseorang dalam melakukan kecurangan adalah teori Fraud Triangle yang dikembangkan oleh Cressey (1953). Teori ini menyatakan bahwa "kecurangan akuntansi disebabkan oleh tiga faktor, yaitu (1) kesempatan (opportunity), (2) tekanan (pressure), dan (3) rasionalisasi (rationalization)".

Kecenderungan kecurangan dipengaruhi oleh ada atau tidaknya kesempatan (opportunity) atau peluang. Peluang yang besar membuat kecenderungan kecurangan lebih sering terjadi. Untuk menangani masalah tersebut, diperlukan monitoring dalam sebuah instansi dan untuk mendapatkan hasil monitoring yang baik, maka diperlukan pengendalian internal yang efektif (Wilopo, 2006).

Pengendalian internal adalah representatif dari keseluruhan kegiatan di dalam organisasi yang harus dilaksanakan untuk memberikan keyakinan yang memadai tentang pencapaian tujuan pengendalian operasional yang efektif dan efisien, keandalan 
Natalia, Edmondus \& Afian

laporan keuangan, serta kepatuhan terhadap hukum (Tunggal, 2011; Mulyadi, 2002). Pengendalian internal yang baik memungkinkan manajemen siap menghadapi perubahan dan persaingan global secara tepat untuk kemajuan yang akan datang. Jika pengendalian internal suatu perusahaan lemah maka kemungkinan terjadinya kesalahan dan kecurangan semakin besar. Sebaliknya, jika pengendalian internalnya kuat, maka kemungkinan terjadinya kecurangan dapat diperkecil.

Penerapan pengendalian internal efektif yang didukung dengan regulasi yang memadai akan mencegah berbagai bentuk persoalan dan ketidakwajaran yang merugikan berbagai pihak yang berkepentingan. Keefektifan pengendalian internal mempunyai pengaruh yang besar dalam upaya pencegahan kecenderungan kecurangan akuntansi. Adanya pengendalian internal yang efektif memungkinkan terjadinya pengecekan silang (cross check) terhadap pekerjaan seseorang oleh orang lain. Hal ini menurunkan peluang terjadinya kecenderungan kecurangan dan mengalokasikan kesalahan.

Kepuasan kerja memiliki dampak pada perilaku yang dihasilkan karyawan dalam melakukan perkerjaanya. Seorang karyawan yang memiliki kepuasan kerja tinggi akan berperilaku positif terhadap pekerjaannya dan diharapkan karyawan tersebut jauh dari perilaku kecurangan akuntansi.

Terkait faktor-faktor yang berpengaruh terhadap kecurangan, beberapa penelitian telah dilakukan sebelumnya, diantaranya adalah penelitian yang dilakukan Wilopo (2006) yang meneliti faktor-faktor yang berpengaruh terhadap kecenderungan kecurangan akuntansi pada perusahaan publik dan BUMN di Indonesia. Hasil penelitian tersebut menunjukkan bahwa perilaku tidak etis manajemen dan kecenderungan kecurangan akuntansi dapat diturunkan dengan meningkatkan keefektifan pengendalian internal, ketaatan aturan akuntansi, moralitas manajemen dan menghilangkan asimetri informasi. Namun, penelitian ini menemukan hal yang bertentangan dengan hipotesis dan teori serta hasil penelitian terdahulu bahwa kompensasi yang sesuai diberikan perusahaan ternyata tidak menurunkan perilaku tidak etis dan kecenderungan kecurangan akuntansi.

Penelitian Meliany (2013) mengungkap bahwa selain efektivitas pengendalian internal, ukuran kesesuaian kompensasi juga merupakan faktor yang mempengaruhi terjadinya kecenderungan kecurangan akuntansi. Hal tersebut juga ditegaskan Thoyibatun (2009) yang menyatakan bahwa kecenderungan kecurangan akutansi tidak hanya dilihat dari pengendalian internal tetapi juga dari kesesuaian kompensasi. Kompensasi yang diterima karyawan harus sesuai dengan kontribusi yang diberikan karyawan kepada organisasi. Hal ini juga dapat meminimalkan tindakan karyawan untuk melakukan kecurangan akuntansi melalui pencurian aset atau penipuan lainnya karena kesejahteraan karyawan diperhatikan dengan baik oleh perusahaan melalui pemberian kompensasi yang sesuai dan adil.

Berdasarkan penelitian yang dilakukan oleh beberapa peneliti terdahulu yang terkait kecenderungan kecurangan akuntansi maka penelitian ini hendak menguji efektifitas pengendalian internal dan kepuasan kerja pada perusahaan BUMN di Makassar. Perbedaan penelitian ini dengan penelitian sebelumnya adalah variabel penelitian dan objek penelitian.

Adapun tujuan dari penelitian ini adalah: (1) untuk mengetahui pengaruh efektifitas pengendalian internal terhadap kecenderungan kecurangan (fraud) pada perusahaan BUMN di Makassar; (2) untuk mengetahui pengaruh kepuasan kerja terhadap 
kecenderungan kecurangan (fraud) pada perusahaan BUMN di Makassar; dan (3) untuk mengetahui pengaruh pengendalian internal, dan kepuasan kerja secara bersama terhadap kecenderungan kecurangan (fraud) pada perusahaan BUMN di Makassar.

Secara teoritis, hasil dari penelitian ini diharapkan dapat memberikan kontribusi bagi pengembangan ilmu dan pengetahuan di bidang akuntansi, terutama berkaitan dengan auditing. Selain itu, penelitian ini juga diharapkan dapat menambah wawasan bagi peneliti selanjutnya terkait literatur akuntansi mengenai pengaruh pengendalian internal dan kepuasan kerja terhadap kecenderungan kecurangan akuntansi. Secara praktis, hasil penelitian ini diharapkan memberikan konstribusi kepada pihak perusahaan berkaitan dengan kecurangan akuntansi karyawan sehingga perusahaan BUMN perlu meningkatkan pengendalian internal perusahaan serta memperhatikan kepuasan kerja karyawan.

\section{B. TELAAH PUSTAKA}

\section{B.1 Kecurangan Akuntansi}

Secara harfiah fraud didefinisikan sebagai kecurangan, namun pengertian ini telah dikembangkan lebih lanjut sehingga mempunyai cakupan yang luas. Istilah kecurangan yang ditulis Tunggal (2012) diartikan sebagai "penipuan di bidang keuangan yang disengaja yang dimaksudkan untuk mengambil aset atau hak orang maupun pihak lain". Menurut Albrecht et al. (2012): "Fraud is a generic term, and embraces all the multifarious means which human ingenuity can devise, which are resorted to by one individual, to get an advantage over another by false representations".

Dari pengertian kecurangan (fraud) di atas, kecurangan adalah istilah umum dan mencakup bermacam-macam arti di mana kecerdikan manusia dapat menjadi alat yang dipilih seseorang untuk mendapatkan keuntungan dari orang lain dengan representasi yang salah.

\section{B.2 Pengendalian Internal}

Tunggal (2011) dalam bukunya mendefinisikan pengendalian internal merupakan rencana organisasi dan metode bisnis yang dipergunakan untuk menjaga aset, memberikan informasi yang akurat dan andal, mendorong dan memperbaiki efisiensi jalannya organisasi dan mendorong kesesuaian dengan kebijakan yang telah ditetapkan. Sementara itu, dalam Peraturan Pemerintah No. 8 Tahun 2006 dijelaskan bahwa: "Pengendalian internal merupakan suatu proses yang dipengaruhi oleh manajemen yang diciptakan untuk memberikan keyakinan yang memadai dalam pencapaian efektivitas, efesiensi, ketaatan terhadap peraturan perundangundangan yang berlaku, dan keandalan penyajian laporan keuangan".

Menurut Mulyadi (2002), pengendalian internal meliputi: "struktur organisasi, metode dan ukuran-ukuran yang dikoordinasikan untuk menjaga kekayaan organisasi, mengecek ketelitian dan keandalan data akuntansi mendorong efisiensi dan mendorong dipatuhinya kebijakan manajemen".

Berdasarkan beberapa pengertian di atas maka dapat disimpulkan bahwa pengendalian internal merupakan suatu proses komprehensif yang dipengaruhi oleh manajemen untuk memberikan keyakinan yang memadai sebagai pedoman untuk meningkatkan efektivitas, efisiensi dan keandalan laporan keuangan serta kepatuhan terhadap hukum.

\section{B.3 Kepuasan Kerja}

Kepuasan kerja seorang karyawan dapat mempengaruhi prestasi kerjanya. Apabila seseorang memperoleh tingkat kepuasan kerja yang tinggi maka akan menghasilkan kinerja yang baik dan 
Natalia, Edmondus \& Afian

menghindari melakukan

kecurangan akuntansi. Gautama (2010) menyatakan kepuasan kerja mempunyai hubungan yang signifikan terhadap kinerja individual. Koesmono (2005) menemukan bahwa kepuasan kerja berpengaruh terhadap kinerja. Luthfia (2009) juga membuktikan bahwa kepuasan kerja berpengaruh terhadap kinerja auditor pada kantor perwakilan BPK Republik Indonesia Provinsi Aceh. Dari beberapa penelitian sebelumnya terbukti bahwa kepuasan kerja berpengaruh terhadap kinerja auditor. Kepuasan kerja merupakan suatu aspek yang penting diperhatikan untuk peningkatan kinerja.

\section{B.4 Pengembangan Hipotesis}

\section{B.4.1 Pengaruh Pengendalian Internal terhadap Kecenderungan Kecurangan (Fraud)}

Sistem pengendalian internal merupakan proses yang dijalankan untuk memberikan keyakinan memadai tentang pencapaian keandalan laporan keuangan, kepatuhan terhadap hukum, dan efektivitas dan efisiensi operasi (Tunggal, 2011). Sistem pengendalian internal yang rendah dan kepatuhan karyawan terhadap pengendalian internal yang juga rendah dapat menjadi pemicu terjadinya kecurangan (fraud) di sektor pemerintahan.

Pengendalian internal yang baik dapat mengurangi atau bahkan menutup peluang untuk melakukan kecenderungan kecurangan akuntansi. Hal ini didukung oleh penelitian yang dilakukan Wilopo (2006), Pristiyanti (2012), Najahningrum (2013), Adelin dan Fauzihardani (2013) yang melihat pengaruh pengendalian internal terhadap kecenderungan kecurangan (fraud). Hasil penelitian mereka menunjukkan bahwa semakin efektif pengendalian internal maka semakin kecil kecenderungan terjadinya kecurangan.
H1: Pengendalian berpengaruh
internal secara parsial

terhadap kecenderungan kecurangan (fraud).

B.4.2 Pengaruh Kepuasan Kerja Terhadap Kecurangan (Fraud)

Kepuasan kerja memiliki dampak pada perilaku yang dihasilkan karyawan dalam melakukan pekerjaan. Karyawan yang memiliki kepuasan kerja tinggi akan berperilaku positif terhadap pekerjaannya dan diharapkan karyawan tersebut jauh dari perilaku kecurangan akuntansi. Kepuasan kerja merupakan salah satu faktor yang penting untuk menentukan kinerja karyawan di suatu instansi ataupun perusahaan. Kepuasan kebutuhan organisasi memang biasanya diasosiasikan dengan uang, sebab uang dapat memenuhi sandang, pangan, dan papan (Rozikin, 2010). Kepuasan kerja terkait dengan masalah lingkungan kerja yang dihadapi oleh karyawan terkait dengan masalah tugas yang diberikan dalam pekerjaan, kesesuaian kompensasi yang didapatkan ataupun rekan pekerjaan (Ananda, 2014).

H2: Kepuasan kerja berpengaruh secara parsial terhadap kecenderungan kecurangan (fraud).

\section{B.4.3 Pengaruh Pengendalian Internal dan Kepuasan Kerja terhadap Kecenderungan Kecurangan (Fraud)}

Kecurangan telah menjadi suatu penyakit yang harus dapat dilawan oleh setiap elemen di instansi atau pemerintah demi tercapainya tujuan pemerintahan. Para ahli memperkirakan bahwa kecurangan yang terungkap merupakan bagian kecil dari seluruh kecurangan yang sebenarnya terjadi. Oleh karena itu, upaya utama seharusnya adalah pada pencegahannya untuk dapat mengurangi kecenderungan kecurangan (fraud). Oleh karena itu, penting untuk dapat mengetahui faktor apa yang dapat mempengaruhi kecenderungan kecurangan sehingga dengan demikian maka pimpinan instansi atau pemerintahan dapat mengambil langkah tepat dalam 
melakukan

kecurangan.

pencegahan

Sehubungan dengan hal tersebut maka terdapat beberapa faktor yang bisa mempengaruhi kecenderungan kecurangan yang oleh peneliti dianggap penting untuk diteliti lebih lanjut yakni pengendalian internal dan kepuasan kerja karyawan. Dari penjelasanpenjelasan sebelumnya, bahwa baik pengendalian internal dan kepuasan kerja memiliki pengaruh terhadap kecenderungan kecurangan tersebut didukung dengan beberapa penelitian yang telah dilakukan sebagaimana yang telah disebutkan di atas. Oleh karena itu, peneliti merasa perlu meneliti pengaruh variabel-variabel tersebut secara bersamaan terhadap kecenderungan kecurangan sehingga dari uraian tersebut dapat ditarik hipotesis sebagai berikut:

H3: Pengendalian internal dan kepuasan kerja berpengaruh secara simultan terhadap kecenderungan kecurangan (fraud).

\section{METODE PENELITIAN}

\section{C.1 Variabel Penelitian}

Penelitian ini terfokus pada pengendalian internal dan kepuasan kerja sebagai variabel independen terhadap kecenderungan kecurangan (fraud) pada perusahaan BUMN di Makassar sebagai variabel dependennya.

\section{C.2 Definisi dan Operasionalisasi Variabel}

C.2.1 Kecenderungan Kecurangan Akuntansi

Pada penelitian ini

kecenderungan kecurangan

akuntansi menjadi variabel dependen. IAI (2001) menjelaskan kecurangan akuntansi sebagai salah saji yang timbul dari kecurangan dalam pelaporan keuangan dan salah saji yang timbul dari perlakuan tidak semestinya terhadap aset (seringkali disebut dengan penyalahgunaan atau penggelapan) berkaitan dengan pencurian aset entitas yang berakibat laporan keuangan tidak disajikan sesuai dengan prinsip akuntansi yang berlaku umum di Indonesia.

\section{C.2.2 Pengendalian Internal}

Pengendalian internal (Tunggal, 2011) merupakan "representatif dari keseluruhan kegiatan di dalam organisasi yang harus dilaksanakan, di mana proses yang dijalankan oleh dewan komisaris ditujukan untuk memberikan keyakinan yang memadai tentang pencapaian tujuan pengendalian operasional yang efektif dan efisien, keandalan laporan keuangan, dan kepatuhan terhadap hukum yang berlaku". Pengendalian internal yang efektif dapat melindungi dari pencurian, penggelapan, penyalahgunaan aset pada lokasi yang tidak tepat. Selain itu, pengendalian internal juga memberikan jaminan yang wajar terhadap informasi bisnis yang akurat demi keberhasilan perusahaan.

\section{C.2.3 Kepuasan Kerja}

Kepuasan kerja memiliki dampak pada perilaku yang dihasilkan karyawan dalam melakukan pekerjaan. Karyawan yang memiliki kepuasan kerja tinggi akan berperilaku positif terhadap pekerjaannya dan diharapkan karyawan tersebut jauh dari perilaku kecurangan akuntansi. Kepuasan kerja merupakan salah satu faktor yang penting untuk menentukan kinerja karyawan di suatu instansi ataupun perusahaan. Kepuasan kebutuhan organisasi memang biasanya diasosiasikan dengan uang, sebab uang dapat memenuhi sandang, pangan, dan papan (Rozikin, 2010). 


\section{C.3 Model Penelitian}

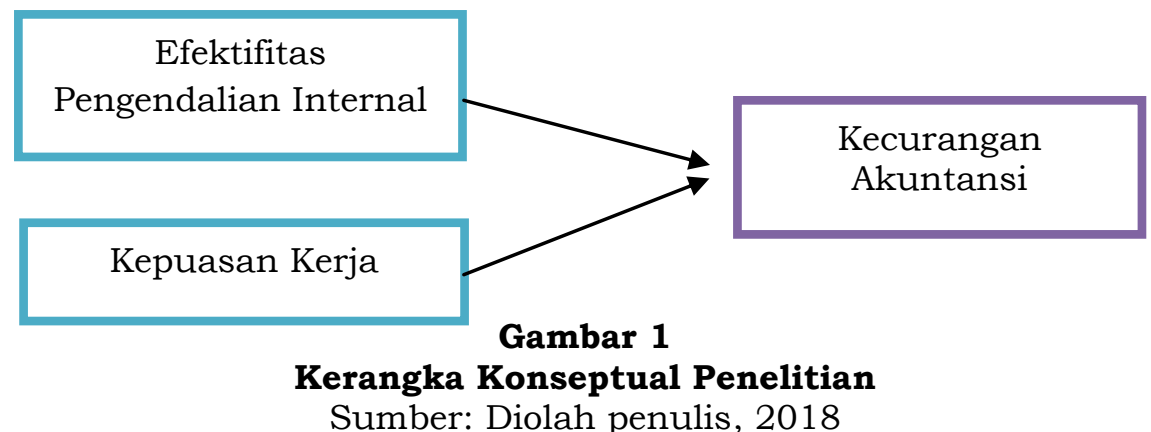

\section{C.4 Populasi dan Sampel}

Populasi dalam penelitian ini adalah karyawan perusahaan BUMN di Makassar. Sampel merupakan sebagian dari populasi yang terpilih sebagai sumber data. Dalam penelitian ini sampel berjumlah 62 orang. Teknik pengambilan sampel yang digunakan dalam penelitian ini adalah purposive sampling dengan kriteria yaitu pegawai bagian keuangan dengan kriteria inklusi: (1) memiliki pengalaman kerja sekurang-kurangnya 1 tahun; dan (2) manajer perusahaan setiap divisi.

\section{C.5 Metode Pengumpulan Data}

Metode pengumpulan data yang digunakan dalam penelitian ini yaitu dengan menggunakan kuesioner untuk mendapatkan data primer. Kuesioner adalah daftar pertanyaan terstruktur yang diajukan pada responden. Kuesioner diberikan kepada karyawan perusahaan BUMN di Makassar yang memenuhi kriteria sebagaimana disebutkan sebelumnya. Dalam pengukurannya, setiap responden diminta pendapatnya mengenai suatu pernyataan, dengan skala penilaian dari 1 sampai dengan 5 . Kuesioner dalam penelitian ini diadaptasi dari Wilopo (2006) dan Aranta (2013).

\section{C.6 Metode Analisis Data}

Untuk menguji seberapa besar pengaruh variabel bebas (X1, X2 dan X3) terhadap variabel Y maka akan diuji dengan analisis regresi berganda dengan rumus sebagai berikut:

$\mathrm{Y}=\mathrm{a}+\mathrm{b}_{1} \mathrm{X}_{1}+\mathrm{b}_{2} \mathrm{X}_{2}+\hat{\mathrm{e}}$

Keterangan:

Y : Kecurangan Akuntansi

a : konstanta

b : koefisien dari variabel bebas

$\mathrm{X}_{1}$ : koefisien regresi variabel pengendalian internal

$\mathrm{X}_{2}$ : koefisien regresi variabel kepuasan kerja

$\mathrm{e}$ : standard error

\section{HASIL DAN PEMBAHASAN}

\section{D.1 Deskripsi Objek Penelitian}

Penyajian statistik deskriptif bertujuan untuk menggambarkan karakteristik sampel dalam penelitian serta memberikan deskripsi masing-masing variabel yang digunakan. Dalam penelitian ini variabel yang digunakan adalah pengendalian internal, kepuasan kerja, dan kecenderungan kecurangan (fraud). Berikut adalah deskripsi statistik dari masingmasing variabel. 
Tabel 1

Statistik Deskriptif

\begin{tabular}{|l|c|c|c|c|c|c|}
\hline \multicolumn{1}{|c|}{ Variabel } & N & Minimum & Maksimum & Mean & Median & $\begin{array}{c}\text { Std. } \\
\text { Deviation }\end{array}$ \\
\hline $\begin{array}{l}\text { Pengendalian } \\
\text { Internal }\end{array}$ & 65 & 19 & 42 & 30,5 & 30 & 3,69 \\
\hline $\begin{array}{l}\text { Kepuasan } \\
\text { Kerja }\end{array}$ & 65 & 8 & 25 & 16,5 & 15 & 3,79 \\
\hline $\begin{array}{l}\text { Kecurangan } \\
\text { Akuntansi }\end{array}$ & 65 & 30 & 69 & 49,5 & 45 & 7,54 \\
\hline
\end{tabular}

Sumber: Diolah penulis, 2018

Tabel 1 menunjukkan hasil pengukuran deskripsi statistik masing-masing variabel dari 65 data pengamatan. Pada tabel tersebut terlihat bahwa variabel pengendalian internal memiliki kisaran empiris antara 19 sampai dengan 42 dengan nilai rata-rata (mean) sebesar 30,5 dan standar deviasi sebesar 3,69. Dengan nilai rata-rata sebesar 30,5 yang lebih tinggi dari nilai tengah (median) sebesar 30, hal tersebut menunjukkan bahwa responden merasa pengendalian internal di perusahaan BUMN telah berjalan cukup baik.

Sedangkan dari variabel kepuasan kerja dari Tabel 1 menunjukkan kisaran empiris antara 8 sampai dengan 25 dengan nilai rata-rata (mean) sebesar 16,5 dan standar deviasi sebesar 3,79. Dengan nilai rata-rata tersebut yakni 16,5 yang lebih tinggi dari nilai tengah (median) sebesar 15 menunjukkan bahwa responden merasa kompensasi yang diberikan kepada karyawan perusahaan BUMN sudah cukup sesuai.

Berdasarkan hasil analisis statistik deskriptif yang ditampilkan pada tabel 1 di atas, nilai standar deviasi dari variabel $\mathrm{X} 1, \mathrm{X} 2$ dan $\mathrm{Y}$ adalah 3,69; 3,79; dan 7,54 menunjukkan angka yang lebih kecil bila dibandingkan dengan nilai rata-rata (mean) pada variabelvariabel tersebut sebesar 30,$5 ; 16,5$; dan 49,5. Hal ini menunjukkan hasil yang baik karena standar deviasi yang merupakan penyimpangan dari data tersebut lebih kecil dari nilai rata-ratanya.

\section{D.2 Pengujian Hipotesis}

Pengujian uji T (uji parsial) dilakukan dalam penelitian ini untuk menguji apakah setiap variabel bebas yaitu pengendalian internal dan kepuasan kerja mempunyai pengaruh yang signifikan terhadap variabel terikat yaitu kecenderungan kecurangan (fraud) secara parsial. Dengan tingkat signifikansi menggunakan a $=5 \%$ dan derajat kebebasan $(\mathrm{df})=\mathrm{n}$ $-2=65-2=63$. Dengan merujuk pada tabel $\mathrm{t}$, maka diperoleh hasil dari t tabel yaitu sebesar 1,998.

Variabel pengendalian internal berpengaruh secara positif dan signifikan terhadap kecenderungan kecurangan (fraud) di perusahaan BUMN di Makassar. Hal ini terlihat dari nilai probabilitasnya yaitu 0,001 yang lebih kecil dari 0,05. Nilai $t$ hitung $(3.765)>t$ tabel $(1,998)$ artinya jika ditingkatkan variabel pengendalian internal sebesar satu satuan, maka kecenderungan kecurangan (fraud) tidak akan bertambah sebesar 0,789. Pengendalian internal berpengaruh secara parsial terhadap kecenderungan kecurangan (fraud).

Variabel kepuasan kerja berpengaruh secara positif dan signifikan terhadap kecenderungan kecurangan (fraud) di perusahaan BUMN di Makassar. Hal ini terlihat dari nilai probabilitasnya yaitu 0,001 yang lebih kecil dari 0,05. Nilai thitung $(3.612)>t$ tabel $(1,998)$ artinya jika ditingkatkan variabel kompensasi sebesar satu satuan maka kecenderungan kecurangan (fraud) tidak akan meningkat sebesar 0,887 . 
Natalia, Edmondus \& Afian

Konstanta sebesar 13.771 artinya walaupun variabel bebas bernilai nol maka kecenderungan kecurangan (fraud) di perusahaan BUMN di Makassar tetap sebesar 13.771. Berdasarkan hasil uji $T$ maka rumus persamaan regresinya adalah:
$\mathrm{Y}=13.771+0.696 \mathrm{X} 1+0.785 \mathrm{X} 2$

Uji F (uji simultan) dilakukan untuk menguji apakah hipotesis yang diajukan dapat diterima ataupun ditolak. Hasil analisis uji $\mathrm{F}$ dalam penelitian ini adalah seperti yang tercantum dalam tabel di bawah ini:

Tabel 2

Uji ANOVA

\begin{tabular}{|c|c|c|c|c|c|}
\hline Model & $\begin{array}{c}\text { Sum of } \\
\text { Squares }\end{array}$ & df & $\begin{array}{c}\text { Mean } \\
\text { Square }\end{array}$ & F & P. \\
\hline Regression & 928.144 & 2 & 464.072 & 13.484 & $.000 \mathrm{a}$ \\
Residual & 2150.010 & 62 & 34.678 & & \\
Total & 3078.154 & 64 & & & \\
\hline
\end{tabular}

a. Predictors: (Constant), Kompensasi, Pengendalian Internal

b. Dependent Variable: Kecenderungan Kecurangan (Fraud)

Sumber: Diolah penulis, 2018

Tingkat signifikansi dari yang digunakan dalam pengujian ini ialah $\mathrm{a}=5 \%$, derajat kebebasannya ialah $\mathrm{df}_{1}$ (jumlah variabel -1 ) $=3-1$ $=2$ dan $\mathrm{df}_{2}(\mathrm{n}-$ jumlah variabel $)=$ $65-3=62$. Setelah melihat tabel $\mathrm{F}$, maka hasil yang diperoleh untuk $F$ tabel ialah sebesar 3,145. Dari tabel di atas, mengungkapkan bahwa nilai $F$ hitung adalah 13.484 dengan tingkat probabilitasnya $<0,001$. Dari kedua perhitungan, diketahui bahwa $F$ hitung $>F$ tabel yaitu $13.484>3,145$ dan nilai probabilitasnya $<0,001<0,05$ yang menunjukkan bahwa adanya pengaruh variabel independen yaitu pengendalian internal dan kepuasan kerja secara serempak adalah signifikan terhadap kecenderungan kecurangan (fraud).

\section{D.3 Pembahasan}

Dalam pengujian secara parsial (uji T) menunjukkan bahwa, variabel pengendalian internal berpengaruh secara positif dan signifikan terhadap kecenderungan kecurangan (fraud) di perusahaan BUMN di Makassar. Hal ini terlihat dari nilai probabilitasnya yaitu 0,001 yang lebih kecil dari 0,05 dan nilai $t$ hitung 3.662 yang lebih besar dari $t$ tabel 1.998 artinya jika ditingkatkan variabel pengendalian internal sebesar satu satuan maka kecenderungan kecurangan (fraud) tidak akan bertambah sebesar 0,696.

Dengan demikian hipotesis pertama (H1) "Pengendalian internal berpengaruh secara parsial terhadap kecenderungan kecurangan (fraud)" dapat diterima. Hal ini menunjukkan bahwa semakin baik pengendalian internal di suatu instansi maka dapat menurunkan tingkat kecenderungan kecurangan (fraud) di sektor pemerintahan. Ini sesuai dengan hasil penelitianpenelitian sebelumnya yang dilakukan Wilopo (2006), Pristiyanti (2012), Najahningrum et al. (2013), dan Adelin dan Fauzihardani (2013) yang juga melihat pengaruh pengendalian internal terhadap kecenderungan kecurangan (fraud). Hasil penelitian mereka menunjukkan bahwa semakin efektif pengendalian internal maka semakin kecil kecenderungan terjadinya kecurangan.

Sementara itu, dari hasil uji yang sama secara parsial (uji T), variabel kepuasan kerja juga berpengaruh secara positif dan signifikan terhadap kecenderungan kecurangan (fraud) di perusahaan BUMN di Makassar. Hal ini terlihat dari nilai probabilitasnya yaitu 0,001 yang lebih kecil dari 0,05. Nilai $t$ hitung 3.510 yang lebih besar $t$ tabel 1,998 artinya jika ditingkatkan variabel kepuasan 
kerja sebesar satu satuan, maka kecenderungan kecurangan (fraud) tidak akan meningkat sebesar 0,785 .

Dengan demikian hipotesis kedua (H2) "Kepuasan kerja berpengaruh secara parsial terhadap kecenderungan kecurangan (fraud)" dapat diterima. Hal ini menunjukkan bahwa semakin tinggi tingkat kepuasan kerja pegawai di suatu instansi maka dapat menurunkan tingkat kecenderungan kecurangan (fraud). Ini sesuai dengan hasil penelitianpenelitian sebelumnya yang dilakukan Putri (2014) dan Julyana (2015) yang juga melihat pengaruh kepuasan kerja terhadap kecenderungan kecurangan (fraud). Hasil penelitian mereka menunjukkan bahwa semakin tinggi tingkat kepuasan kerja maka semakin kecil kecenderungan terjadinya kecurangan.
Dalam pengujian Anova (Uji F), diperoleh hasil bahwa $F$ hitung $>F$ tabel yaitu $13.484>3,145$ dan nilai probabilitasnya $(<0,001)<0,05 \mathrm{di}$ mana angka tersebut menunjukkan bahwa adanya pengaruh variabel independen yaitu pengendalian internal dan kompensasi secara serempak adalah signifikan terhadap kecenderungan kecurangan (fraud) di perusahaan BUMN di Makassar. Dari hasil yang diperoleh ini, sesuailah dengan hipotesis yang ketiga (H3) yaitu "pengendalian internal dan kepuasan kerja berpengaruh secara simultan terhadap pencegahan kecenderungan kecurangan (fraud) di perusahaan BUMN di Makassar". Dalam pengujian koefisien determinasi $\left(R^{2}\right)$, yang tercantum dalam tabel di bawah ini:

Tabel 3

Uji Determinan $\left(\mathbf{R}^{2}\right)$ Model Summaryb

\begin{tabular}{|c|c|c|c|c|c|}
\hline Model & $\mathbf{R}$ & R Square & $\begin{array}{c}\text { Adjusted } \\
\text { R Square }\end{array}$ & $\begin{array}{c}\text { Std. Error } \\
\text { of the } \\
\text { Estimate }\end{array}$ & $\begin{array}{c}\text { Durbin- } \\
\text { Watson }\end{array}$ \\
\hline $\begin{array}{c}\text { dimension } \\
01\end{array}$ & $.545 a$ & .297 & .267 & 5.88877 & 1.620 \\
\hline
\end{tabular}

a. Predictors: (Constant), Kompensasi, Pengendalian Internal

b. Dependent Variable: Kecenderungan Kecurangan (Fraud)

Sumber: Diolah penulis, 2018

Tabel di atas menunjukkan daya ramal model sebesar $29,7 \%$ yang diperoleh dari nilai $R$ Square 0,297. Sedangkan tingkat pengaruh variabel independen yaitu pengendalian internal dan kepuasan kerja secara bersama terhadap kecenderungan kecurangan (fraud) di perusahaan BUMN di Makassar ialah sebesar sebesar $26,7 \%$ dan sisanya $73,3 \%$ dipengaruhi oleh faktor lain di luar kedua variabel independen dalam penelitian ini. Angka tersebut dapat dilihat dari Tabel 4 di mana Adjusted $R$ Square yang diperoleh adalah sebesar 0,267 atau $26,7 \%$.

\section{E. PENUTUP}

\section{E.1 Kesimpulan}

Berdasarkan hasil temuan penelitian dan pengujian hipotesis yang telah dilakukan dapat disimpulkan bahwa:

1. Pengendalian internal berpengaruh positif dan signifikan terhadap kecenderungan kecurangan (fraud). Hasil temuan ini sesuai dengan hasil penelitianpenelitian sebelumnya yang dilakukan Wilopo (2006), Pristiyanti (2012), Najahningrum (2013), Adelin dan Fauzihardani (2013), sehingga penelitian ini didukung. Hal ini membuktikan bahwa semakin baik 
pengendalian internal di sebuah instansi maka semakin rendah kecenderungan kecurangan.

2. Kepuasan kerja berpengaruh berpengaruh positif dan signifikan terhadap kecenderungan kecurangan (fraud). Hasil temuan ini sesuai dengan hasil penelitianpenelitian sebelumnya yang dilakukan Putri (2014) dan Julyana (2015). Hal ini membuktikan bahwa semakin tinggi tingkat kepuasan kerja karyawan di sebuah instansi maka semakin rendah kecenderungan kecurangan.

3. Pengaruh pengendalian internal dan kepuasan kerja karyawan secara bersama terhadap kecenderungan kecurangan (fraud) di perusahaan BUMN di Makassar ialah sebesar sebesar $27,9 \%$ dan sisanya $72,1 \%$ dipengaruhi oleh faktor lain di luar kedua variabel independen dalam penelitian ini.

\section{E.2 Saran}

Penelitian selanjutnya dapat mengembangkan beberapa hal yakni memperluas obyek penelitian yang tidak terbatas pada perusahaan BUMN saja baik di kota Makassar maupun di kota lainnya dan menambahkan variabel lain yang diperkirakan mempengaruhi kecenderungan kecurangan seperti ketaatan hukum, komitmen organisasi dan moralitas. Hasil penelitian ini diharapkan dapat memberikan masukan bahwa pengendalian internal dan kepuasan kerja karyawan memiliki pengaruh yang signifikan terhadap tingkat kecenderungan kecurangan (fraud). Bagi pihak perusahaan BUMN di Makassar dapat lebih mengefektifkan dan mengembangkan pengendalian internal (penerapan wewenang dan tangggung jawab, komunikasi dan informasi serta pengawasan dan evaluasi) dan pemberian kompensasi yang sesuai (khususnya gaji dan tunjangan) dan menghidupkan lingkungan kerja yang nyaman bagi karyawan agar dapat menekan terjadinya praktik kecurangan.

\section{DAFTAR PUSTAKA}

Adelin, V. dan Fauzihardani, E. 2013.

Pengaruh Pengendalian Internal, Ketaaatan pada Aturan Akuntansi dan Kecenderungan Kecurangan Terhadap Perilaku Tidak Etis. WRA, Vol. 1.(2).

Albrecht, W., et.al. 2012. Fraud Examination. Connecticut: Cengage Learning.

Ali, M. 2007. Kamus Lengkap Bahasa Indonesia Modern. Pustaka Amani. Jakarta.

Ananda A.P. 2014. Pengaruh Keefektifan Pengendalian Internal dan Kepuasan Kerja terhadap Kecenderungan Kecurangan Akuntansi pada Dinas Pendapatan Pengelolaan Keuangan Aset Daerah Istimewa Yogyakarta, Jurnal Nominal, Vol III, (1).

Aranta, P.Z. 2013. Pengaruh Moralitas Aparat Dan Asimetri Informasi Terhadap Kecenderungan Kecurangan Akuntansi (Studi Empiris Pemerintah Kota Sawahlunto). (Online), (ejournal.unp.ac.id, diakses 28 Maret 2016).

Hall, J.A. 2011. Principles of Accounting Information systems., Asia Edition. Cengage Learning.

Fatir, D. 2013. Catatan Akhir Tahun - Korupsi Barang Dan Jasa Dominasi 2013. (Online), (http://www.antarasulawesiselatan.com, diakses 29 Feb 2016).

Fauwzi, M.G. 2011. Pengaruh Keefektifan Pengendalian Internal, Kesesuaian Kompensasi, dan Moralitas 
Manajemen Terhadap Perilaku Tidak Etis dan Kecenderungan Kecurangan Akuntansi. Skripsi. Semarang: Universitas Diponegoro.

$\begin{array}{lr}\text { Gautama. 2010. } & \text { Pengaruh } \\ \text { Kepuasan } & \text { Kerja, } \\ \text { Profesionalisme, } & \text { Dan } \\ \text { Penerapan } & \text { Teknologi } \\ \text { Informasi Terhadap Kinerja } \\ \text { Auditor. Jurnal Telaah dan } \\ \text { Riset Akuntansi. } & \text { 3(2) p 195- } \\ \text { 205. }\end{array}$

Ikatan Akuntansi Indonesia. 2001. Standar Profesional Akuntan Publik, Cetakan Kedua. Salemba Empat, Jakarta.
Juliyana. 2015. Pengaruh Pengendalian Internal, Kepuasan Kerja, Moralitas Manajemen, Dan Budaya Etis Organisasi Terhadap Kecenderungan Kecurangan Akuntansi. Jurnal Akuntansi dan Sistem Teknologi Informasi. Vol. 11, pp 135 - 144.

Kompasiana. 2013. 10 Tahun KPK! Indonesia Paling Korup di Asia Pasifik!. (Online). (http: / / politik.kompasiana.c om, diakses 19 Feb 2016).

Meliany, L. dan H. Ernawati. 2013. Pengaruh Keefektifan Pengendalian Internal dan Kesesuaian Kompensasi Terhadap Kecenderungan Kecurangan Akuntansi. Journal \& Proceeding Universitas Jenderal Soedirman, Vol III, No.1. Hal. 1-10.

Mulyadi. 2002. Auditing. Salemba Empat, Jakarta.

Najahningrum A.F. 2013. FaktorFaktor yang Mempengaruhi Kecenderungan Kecurangan (Fraud): Persepsi Pegawai Dinas Provinsi DIY.

\author{
Simposium Nasional \\ Akuntansi XVI Manado.
}

Peraturan Pemerintah Republik Indonesia No. 8 Tahun 2006 tentang Sistem Pengendalian Internal Pemerintah. 2006. Jakarta: Departemen Keuangan Republik Indonesia

Pristiyanti, I.R. 2012. Persepsi Pegawai Instansi Pemerintah Mengenai Faktor-Faktor yang Mempengaruhi Fraud di Sektor Pemerintahan. Accounting Analysys Journal AAJ 1(1).

Putri, A. 2014. Pengaruh Keefektifan Pengendalian Internal Dan Kepuasan Kerja Terhadap Kecenderungan Kecurangan Akuntansi Pada Dinas Pendapatan Pengelolaan Keuangan Aset Daerah Istimewa Yogyakarta. Jurnal Nominal, Vol.3 No 1.pp 61-74.

Rahayu, T. 2014. Pengaruh Profesionalisme Auditor Internal Terhadap Pengungkapan Kecurangan. Skripsi. Fakultas Ekonomi. Universitas Widyatama. Bandung.

Sekaran, U. 2009. Research Methods For Business (Metodologi Penelitian untuk Bisnis. Salemba Empat, Jakarta.

Sugiyono. 2011. Metode Penelitian Kuantitatif kualitatif dan $R \& D$. Bandung: Alfabeta.

Tuanakotta, T.M. 2007. Akuntansi Forensik dan Audit Investigatif. Jakarta: Lembaga Penerbit Fakultas Ekonomi Universitas Indonesia.

Tunggal, A.W. 2011. Teori dan Kasus Internal Auditing. Jakarta: Harvarindo. 
Efektivitas Pengendalian Internal, Kepuasan Kerja ... Natalia, Edmondus \& Afian

Wilopo. 2006. Analisis Faktor-Faktor yang Berpengaruh terhadap Kecenderungan Kecurangan Akuntansi: Studi pada Perusahaan Publik dan Badan Usaha Milik Negara di Indonesia. Simposium
Nasional Akuntansi IX Padang.

Zulkarnain, R.M. 2013. Analisis Faktor yang Mempengaruhi Terjadinya Fraud pada Dinas Kota Surakarta. Accounting Analysis Journal AAJ 1(3). 